\title{
Liver Total Glycogen, Mitochondrial Protein and CoQ10 Analysis in CoQ10 Supplemented Broiler Chicken
}

\author{
J. Ramavathi*, P. Selvaraj, P. Visha, Manju G. Preeda and V. Thavasiappan \\ Department of Veterinary Physiology, VCRI, Namakkal, India \\ *Corresponding author:
}

\section{Keywords \\ CoQ10, \\ Mitochondrial \\ protein, \\ Liver CoQ10, \\ Glycogen \\ Article Info \\ Accepted: \\ 07 March 2019 \\ Available Online: \\ 10 April 2019}

\section{A B S T R A C T}

A Pilot study was conducted to find out the level of $\mathrm{CoQ}_{10}$ inclusion in broiler diet to bring about better performance and conducted during the period from November to December. Fifty numbers of day old broiler straight run chicks were wing banded, weighed and randomly allotted to five groups of ten chicks each based on the body weight. The treatments include, $20 \mathrm{mg}, 40 \mathrm{mg}, 60 \mathrm{mg}, 80 \mathrm{mg}, 100 \mathrm{mg}$ of $\mathrm{CoQ}_{10} / \mathrm{kg}$ diet. Based on the results of FCR in pilot study experiment II was conducted with Two hundred and forty (240) numbers of day old broiler straight run chicks were wing banded, weighed and randomly allotted to 5 groups 6 replicates of eight chicks each based on the body weight. The treatments were, Basal diet without $\mathrm{CoQ}_{10}$ supplementation, Low energy diet without $\mathrm{CoQ}_{10}$ supplementation, Low energy diet with $20 \mathrm{mg}$ of $\mathrm{CoQ}_{10} / \mathrm{kg}$ diet, Low energy diet with $40 \mathrm{mg}$ of $\mathrm{CoQ}_{10} / \mathrm{kg}$ diet, Low energy diet with $60 \mathrm{mg}$ of $\mathrm{CoQ}_{10} / \mathrm{kg}$ diet. Glycogen content of the liver was estimated as per the method of Seifter et al., (1949). Hepatic mitochondria were obtained by differential centrifugation as outlined by Cawthon et al., (1999). Mitochondrial protein concentration was estimated as per the method of Lowry et al., (1971). The $\mathrm{CoQ}_{10}$ content of liver was extracted as per the method of (Barros et al., 2011) and liver $\mathrm{CoQ}_{10}$ level was estimated as per the method of (Ioana et al., 2009). The mean liver glycogen $(\mu \mathrm{g} / \mathrm{g})$ was $152.66,167.55,169.14,171.13$ in the treatment groups T2 to T5 as compared with 158.45 in the control group of broiler chickens. The mean liver glycogen was significantly $(\mathrm{P}<0.05)$ highest in the $\mathrm{Co} \mathrm{Q}_{10}$ supplemented groupof birds $(\mathrm{T} 3$, T4 and T5) in comparison to control and T2 group. There was no significant difference in mean liver glycogen among the treatment groups T4 and T5. The mean liver glycogen was significantly $(\mathrm{P}<0.05)$ lowest in the control and T2 group of birds. The mean liver mitochondrial protein concentration $(\mu \mathrm{g} / \mathrm{g})$ was $15.90,24.70,22.00$ and 23.20 in the treatment groups T2 to T5 as compared with 19.70 in the control group of broiler chickens. The mean liver mitochondrial protein concentration was significantly $(\mathrm{P}<0.05)$ highest in the $\mathrm{CoQ}_{10}$ supplemented group of birds (T3, T4 and T5) in comparison to control and T2 groups. The mean liver $\mathrm{CoQ}_{10}(\mathrm{mg} / \mathrm{kg})$ was $49.26,54.53,55.75$ and 55.74 in the treatment groups as compared with 53.83 in the control group of chicken. 


\section{Introduction}

India has vast resource of livestock and poultry, which play a vital role in improving the socio-economic conditions of the rural masses. Among different countries in the World, India owns considerable proportion of livestock and poultry wealth. As per 2012 livestock census, India possessed 512.06 million livestock and 729.21 million poultry. However, the annual growth rate of livestock population in India during 2007 to 2012 implied that the total livestock population had marginal negative trend at 0.68 per cent and the total poultry population had annual compound growth rate of 2.36 per cent. The scenario of livestock population in Tamil Nadu over the last two census periods implied that the total livestock and poultry population had negative growth rate of 5.88 per cent and 1.74 per cent, respectively. Poultry industry occupies a major position in the livestock sector of agricultural production because birds reproduce much quicker to produce meats and eggs for human consumption within the shortest possible time (Sanni and Ogundipe, 2005).An increasing in per capita consumption by one egg and 50 grams of poultry meat can create employment for about 26,000 persons per year (Kazi, 2003). The present per capita availability of poultry meat is $1.8 \mathrm{~kg}$ against the requirement of $11 \mathrm{~kg}$, as per the National Committee on Human Nutrition in India (www.indiastat.com, 2006).

In India, the production of broilers increased from 1.89 lakh tones in 1989-90 to 23.13 lakh tones in2009-10, at a compound annual growth rate of 13.21 per cent. In broiler production, India stands $5^{\text {th }}$ in the world with 2.31 million tones of broiler meat, contributing Rs 9000 crore to the national economy. Coenzyme $\mathrm{Q}_{10}\left(\mathrm{CoQ}_{10}\right)$ is a naturally occurring compound with a ubiquitous distribution in nature. Based on an isoprenoid moiety, the presence of various CoQ homologs has been confirmed. CoQ10, which has a polyisoprene chain containing 10 isoprene units, was predominant in humans and birds, whereas CoQ9 was predominant in rats and mice (lbano et al., 2002). Hagavan et al., (2006) stated that $\mathrm{CoQ}_{10}$ acts as an electron carrier in the mitochondrial respiratory chain and as a lipid-soluble antioxidant. Kamisoyama (2010) found that dietary $\mathrm{CoQ}_{10}$ significantly reduced the levels of cholesterol in the egg yolks of laying hens, but the mechanisms underlying this reduction in egg-yolk cholesterol have not been identified.

In chickens, dietary $\mathrm{CoQ}_{10}$ supplementation reduced broiler chickens susceptibility to ascites, perhaps as a result of improved hepatic mitochondrial function, respiratory chain-related enzyme activities, and the mitochondrial antioxidant activity of $\mathrm{CoQ}_{10}$. Nakamura (1996) stated that fed broiler chicks diets supplemented with coenzyme Q9, an analogue of $\mathrm{CoQ}_{10}$, at $40 \mathrm{mg} / \mathrm{kg}$ and showed that dietary coenzyme Q9 supplementation was beneficial in reducing ascites incidence in broiler chicks.

Geng et al., (2010) reported that the mortality of broilers due to ascites was reduced by Lcarnitine and $\mathrm{CoQ}_{10}$ supplementation alone and in combination the reason may be partially associated with the antioxidative effects of these substances.

In broiler chicken higher body weight gain and better feed efficiency with less feed cost per kilogram weight gain was observed in high energy group supplemented with $20 \mathrm{mg}$ of $\mathrm{CoQ}_{10} / \mathrm{kg}$ diet and the dressing percentages, weight of giblet, liver, spleen, abdominal fat, intestinal length were not significantly altered by CoQ10 supplementation but the heart weight, gizzard weight and ascites heart weight (AHI) were significantly decreased due to $\mathrm{CoQ}_{10}$ supplementation (gopi et al., 2014). 


\section{Materials and Methods}

\section{Experiment I (Pilot study)}

Pilot study was conducted to find out the level of $\mathrm{CoQ}_{10}$ inclusion in broiler diet to bring about better performance. Pilot study was conducted during the period from November to December-2015. Fifty numbers of day old broiler straight run chicks were wing banded, weighed and randomly allotted to five groups of ten chicks each based on the body weight.

The treatments include, 20mg, 40mg,60mg,80mg,100mg of $\mathrm{CoQ}_{10} / \mathrm{kg}$ diet.

\section{Experiment II}

Two hundred and forty (240) numbers of day old broiler straight run chicks were wing banded, weighed and randomly allotted to 5 groups 6 replicates of eight chicks each based on the body weight. The treatments were $\left(\mathrm{T}_{1}\right.$ $-\mathrm{T}_{5}$ ), Basal diet without $\mathrm{CoQ}_{10}$ supplementation, Low energy diet without $\mathrm{CoQ}_{10}$ supplementation, Low energy diet with $20 \mathrm{mg}$ of $\mathrm{CoQ}_{10} / \mathrm{kg}$ diet, Low energy diet with $40 \mathrm{mg}$ of $\mathrm{CoQ}_{10} / \mathrm{kg}$ diet, Low energy diet with $60 \mathrm{mg}$ of $\mathrm{CoQ}_{10} / \mathrm{kg}$ diet.

\section{Total glycogen}

Glycogen content of the liver was estimated as per the method of Seifter et al., (1949). Briefly, immediately after slaughter $1 \mathrm{~g}$ of liver is dropped into a previously weighed test tube containing $3 \mathrm{ml}$ of $30 \% \mathrm{KOH}$. After delivery of the sample, the test tube and its contents were reweighed and weight of sample determined by difference. The tissue was digested by heating the tube for $20 \mathrm{~min}$ in a boiling water bath and then the digest was cooled. $5 \mathrm{ml}$ of aliquot was taken from this digest and transferred to the $50 \mathrm{ml}$ volumetric flask. The contents were diluted to the mark with double distilled water. Again $5 \mathrm{ml}$ of aliquot was taken from this contents and diluted in another $50 \mathrm{ml}$ volumetric flask.. Five $\mathrm{ml}$ aliquots of the final dilution were pipette into a glass tube. While submerged in cold water the test tube received $10 \mathrm{ml}$ of the anthrone reagent. The tubes were vortexed and absorbance was taken at $620 \mathrm{~nm}$ in UV spectrophotometer.

\section{Mitochondrial protein concentration}

\section{Preparation of mitochondria}

Hepatic mitochondria were obtained by differential centrifugation as outlined by Cawthon et al., (1999). Approximately $2 \mathrm{~g}$ of liver tissue was suspended in $5 \mathrm{ml}$ of isolation media (PH7.4) containing $220 \mathrm{mM}$ dmannitol,70mM sucrose, $2 \mathrm{mM}$ HEPES, 0.5 $\mathrm{mg} / \mathrm{ml} \mathrm{BSA}$ and $1 \mathrm{mM}$ EGTA.The tissue was homogenized with a hand driven glass-teflon homogenizer. Aliquots were transferred into centrifuge tubes \& centrifuged twice for $10 \mathrm{~min}$ at $600 \mathrm{~g}$. The pellets containing nuclei and cell debris were discarded and the supernatant was centrifuged for $15 \mathrm{~min}$ (7750g).

The mitochondrial pellets were resuspended in an isolation buffer ( $\mathrm{PH}$ 7.0) containing $220 \mathrm{mM}$ d-mannitol, $70 \mathrm{mM}$ sucrose, $2 \mathrm{mM}$ HEPES and $0.5 \mathrm{mg} / \mathrm{ml}$ BSA and were washed twice. Mitochondria were resuspended in incubation media $(210 \mathrm{mM}$ d-mannitol, $70 \mathrm{mM}$ sucrose, $2 \mathrm{mM}$ HEPES and $10 \mathrm{mM}$ succinate) and placed on ice.

\section{Estimation of mitochondrial protein concentration}

Mitochondrial protein concentration was estimated as per the method of Lowry et al., 1971. Briefly, standard curve was prepared by using BSA as standard at different concentration. $200 \mu \mathrm{L}$ of sample was added with $2 \mathrm{~mL}$ of alkaline copper sulphate 
solution and then $0.2 \mathrm{~mL}$ of Folin Ciocaltaeau was added in the test tube. The reagents were incubated for 30min.The absorbance was recorded by using spectrophotometer at $660 \mathrm{~nm}$.

\section{Liver $\operatorname{CoQ}_{10}$}

The $\mathrm{CoQ}_{10}$ content of liver was extracted as per the method of (Barros et al., 2011) and liver $\mathrm{CoQ}_{10}$ level was estimated as per the method of (Ioana et al., 2009).

\section{Results and Discussion}

Based on the body weight and feed conversion ratio of the birds in experiment 1 concluded that the mean body weight was not affected by $\mathrm{CoQ}_{10}$ supplementation at graded levels. Supplementation of broiler chickens with normal diet without $\mathrm{CoQ}_{10}$ supplementation (T1) and low energy diet (100kcal less) with $\mathrm{CoQ}_{10}$ supplementation $(20 \mathrm{mg} / \mathrm{kg}$ diet) (T3) resulted in increased body weight gain as compared to other treatment groups T2,T4 and T5. CoQ 10 supplementation did not show any significant difference in the mean body weight gain. But it could show significant difference in the mean feed conversion ratio. The group supplemented with20mg of $\mathrm{CoQ}_{10} / \mathrm{kg}$ diet could show significantly lowest mean FCR in comparison to control group and other $\mathrm{CoQ}_{10}$ supplemented groups (Table 1).

\section{Effect on liver glycogen}

The mean liver glycogen $(\mu \mathrm{g} / \mathrm{g})$ was 152.66 , $167.55,169.14,171.13$ in the treatment groups T2 to T5 as compared with 158.45 in the control group of broiler chickens. The mean liver glycogen was significantly $(\mathrm{P}<0.05)$ highest in the $\mathrm{CoQ}_{10}$ supplemented group of birds (T3, T4 and T5) in comparison to control and T2 group. There was no significant difference in mean liver glycogen among the treatment groups T4 and T5. The mean liver glycogen was significantly $(\mathrm{P}<0.05)$ lowest in the control and $\mathrm{T} 2$ group of birds.

The result of the present study is agreement with the findings of Oztay (2007) in Swiss black mice.

\section{Effect on liver mitochondrial protein concentration}

The mean liver mitochondrial protein concentration $(\mu \mathrm{g} / \mathrm{g})$ was $15.90,24.70,22.00$ and 23.20 in the treatment groups T2 to T5 as compared with 19.70 in the control group of broiler chickens. The mean liver mitochondrial protein concentration was significantly $(\mathrm{P}<0.05)$ highest in the $\mathrm{CoQ}_{10}$ supplemented group of birds (T3, T4 and T5) in comparison to control and $\mathrm{T} 2$ groups.

There was no significant difference in the mean liver mitochondrial protein concentration of T3, T4 and T5 groups. The mean liver mitochondrial protein concentration was significantly $(\mathrm{P}<0.05)$ lowest in the control and T2 group of birds.

The result of the present study is in agreement with the findings of Huang et al., (2011) in broilers, Geng et al., (2006) in broilers and Kwong et al., (2002) in rats.

\section{Effect on liver coenzyme $\mathbf{Q}$}

The mean liver $\mathrm{CoQ}_{10}(\mathrm{mg} / \mathrm{kg})$ was 49.26 , $54.53,55.75$ and 55.74 in the treatment groups as compared with 53.83 in the control group of chicken. The mean liver $\mathrm{CoQ}_{10}$ was $(\mathrm{P}<0.05)$ significantly highest in the $\mathrm{T} 3, \mathrm{~T} 4$ and $\mathrm{T} 5$ group in comparison to control and T2 group. There was no significant difference in the mean liver $\mathrm{Co} \mathrm{Q}_{10}$ level among the treatment groups T3, T4 and T5 (Table 2). 
Table.1 Mean $( \pm$ S.E) cumulative feed conversion ratio of broiler chickens as influenced by dietary inclusion of Co Q10 at graded level

\begin{tabular}{|c|c|c|}
\hline Treatment groups & Body weight & FCR \\
\hline Control & $1850.6^{\mathrm{a}} \pm 36.81$ & $1.93^{\mathrm{c}} \pm 0.02$ \\
\hline T1(20mg) & $1922.3^{\mathrm{c}} \pm 40.12$ & $1.58^{\mathrm{a}} \pm 0.06$ \\
\hline T2(40mg) & $1892.5^{\mathrm{ab}} \pm 42.52$ & $1.60 \pm 0.02$ \\
\hline T3(60mg) & $1899.8^{\mathrm{b}} \pm 39.27$ & $1.58^{\mathrm{a}} \pm 0.06$ \\
\hline T4(80mg) & $1891.2^{\mathrm{ab}} \pm 37.68$ & $1.68^{\mathrm{ab}} \pm 0.04$ \\
\hline T5(100mg) & $1889.8^{\mathrm{ab}} \pm 41.73$ & $1.64^{\mathrm{ab}} \pm 0.02$ \\
\hline $\begin{array}{l}\text { Means within the same column bearing different superscripts differ } \\
\text { significantly (P<0.05) }\end{array}$
\end{tabular}

Table.2

\begin{tabular}{|l|c|c|c|}
\hline Treatment & $\begin{array}{c}\text { Mitochondrial protein } \\
(\mu \mathrm{g} / \mathrm{g})\end{array}$ & $\begin{array}{c}\text { Liver COQ }(\mathrm{mg} / \mathrm{kg}) \\
\mathrm{b}\end{array}$ & $\begin{array}{c}\text { Total glycogen } \\
(\mu \mathrm{g} / \mathrm{g})\end{array}$ \\
\hline T1 (control) & $19.70^{\mathrm{b}} \pm 0.84$ & $53.83^{\mathrm{b}} \pm 0.72$ & $158.45^{\mathrm{c}} \pm 0.64$ \\
\hline T2 & $15.90^{\mathrm{c}} \pm 0.57$ & $49.26^{\mathrm{a}} \pm 0.35$ & $152.66^{\mathrm{d}} \pm 0.64$ \\
\hline T3 & $24.70^{\mathrm{a}} \pm 1.50$ & $54.53^{\mathrm{b}} \pm 0.43$ & $167.55^{\mathrm{a}} \pm 0.25$ \\
\hline T4 & $22.00^{\mathrm{a}} \pm 1.03$ & $55.75^{\mathrm{b}} \pm 0.78$ & $169.14^{\mathrm{b}} \pm 0.76$ \\
\hline T5 & $23.20^{\mathrm{a}} \pm 0.73$ & $55.74^{\mathrm{b}} \pm 0.69$ & $171.13^{\mathrm{b}} \pm 0.62$ \\
\hline
\end{tabular}

Means bearing same superscript do not differ significantly $(\mathrm{P}<0.05)$ 
The results of weight gain and feed conversion ratio are in accordance with that of Geng et al., (2004), Geng et al., (2010), Huang et al., (2011), Gopi et al., (2014), and Honda et al., (2013). However the result of the present study does not agree with findings of Gopi et al., (2014) during prestater and starter periods. It is inferred that $\mathrm{CoQ}_{10}$ supplementation would improve FCR when less energy diet $(100 \mathrm{kcal})$ is practised. Body weight of broilers was increased by supplementation with $\mathrm{CoQ}_{10}$ at $20 \mathrm{mg} / \mathrm{kg}$ diet, but not at 40 and $60 \mathrm{mg} / \mathrm{kg}$ diet. This implied that $\mathrm{CoQ}_{10}$ might have an interaction with age because the positive effect was more pronounced in later period than earlier period. Another possible reason for not producing better performance in birds fed higher $\mathrm{CoQ}_{10}$ in diet might be due to the process of autooxidation of $\mathrm{CoQ}_{10}$ in the body (Turrens et al., 1985). The other reasons might be that long term supplementation with $\mathrm{CoQ}_{10}$ at $40 \mathrm{mg} / \mathrm{kg}$ feed might weaken the beneficial effects of $\mathrm{CoQ}_{10}$ (Huang et al., 2011). The higher feed intake in low energy diet (T2) might be due to the bird's trying to meet its energy requirement. Gopi et al., (2014).The reason for the accumulation of higher glycogen may be due to positive effect of $\mathrm{CoQ}_{10}$ on glycogen synthesis. Mitochondrial protein content in $\mathrm{CoQ}_{10}$ fed birds were significantly increased as compared to control. The increase $(13-21 \%)$ in the mitochondrial protein may be due to the positive effect of $\mathrm{CoQ}_{10}$ on mitochondrial enzymes and their activities. Geng et al., (2006) also found enhanced cytochrome oxidase and $\mathrm{H}^{+}$-ATPase activity when $\mathrm{CoQ}_{10}$ fed to broilers and observed the susceptibility of broiler chicken to ascites. Similarly, Matthews et al., (1998) recorded higher brain mitochondrial enzymes in rats fed $\mathrm{CoQ}_{10}$. Addition of $\mathrm{CoQ}_{10}$ at different level in the broiler diet did not accumulate $\mathrm{CoQ}_{10}$ in liver tissues of birds T3, T4 and T5 groups. The level was almost similar to control. However, the group T2 level was low compared to all the groups. The possible explanation for no change in the liver $\mathrm{CoQ}_{10}$ content of treated birds may be due to unknown mechanism of regulating liver $\mathrm{CoQ}_{10}$ level (Krizman et al., 2012). It has been observed that transfer of $\mathrm{CoQ}_{10}$ to various organs was probably linked to the longer periods of feeding (Krizman et al., 2012).

\section{References}

Barros, C.C.F., Sugawara, E.K. and Sanches, L.R. (2011). Determination of a method for extraction of coenzyme Q10in human plasma: optimization of the use of surfactants and other variables. Einstein, 10(2): 203-8.

Cawthon, D., McNew, R., Beers, K. W. and. Bottje, W. G. (1999). Evidence of mitochondrial dysfunction in broilers with pulmonary hypertension syndrome (ascites): Effect of t-butyl hydroperoxide on hepatic mitochondrial function, glutathione, and related thiols. Poult. Sci., 78:114-124.

Geng, A.L. and Guo, Y.M. (2006). Effects of dietary coenzymeQ10 supplementation on hepatic mitochondrial function and the activities of respiratory chain-related enzymes in ascitic broiler chickens. $B r$. Poult. Sci., 46: 626-634.

Geng, A.L., Guo, Y. and Yuan, J. (2010). Effects of dietarl-carnitine and coenzyme Q10 supplementation on performance and ascites mortality of broilers. Arch Anim Nutr., 58: 473-482.

Gopi, M., Purushothaman, M and Chandrasekaran, D. (2014). Effect of dietary coenzyme Q10 supplementation on the growth rate, carcass characters and cost effectiveness of broiler fed with three energy levels. Springer Plus, 3: 518.

Huang, B., Yuming, G., Xiaofei, H. and Song, Y. (2011). Effects of coenzyme Q10 on 
growth performance and heart mitochondrial function of broilers under high altitude induced hypoxia. J. Poult. Sci., 48: 40-46.

Ioana, V.S., Laslo, V., Uivarosan, D. (2009). Stimulation Of Biosynthesis Of Coenzyme Q10 By Sacharomyces cerevisiae Under The Influence of vitamin B1. Analele Universitatii din oradea: Fascicula Ecotoxicologie, Zootehniesi Tehnologii de Industrie Alimentara.

Kamisoyama, H., Honda, K., Kitaguchi, K. and Hasegawa, S. (2010). Transfer of dietary coenzyme Q10 into the egg yolk of laying hens. J. Poult Sci., 47: 28-33.

Kazi, S.S. (2003). Poultry industry, wheeling on fast lane. Agriculture Today, 6 (5): 45-48.

Krizman, P.J., Prosek, M., Smidovnik, A., Wondra, A.G., Glaser, R., Zelenko, B. and Volk, M. (2012). Poultry products with increased content of CoQ10 prepared from chickens fed with supplemental CoQ10. Ch. 9th. In: Eissa AHA (ed). Trends in Vital Food and control engineering. In. Tech. Rijeka, Croatia., 165-186.

Kwong, L.K., Kamzalov, S., Rebrin, I., Bayne, A.V., Jana, C.K., Morris, P., Forster, M.J and Sohal, R.S. (2002). Effects of coenzyme q10 administration on its tissue concentrations, mitochondrial oxidant generation, and oxidative stress in the rat. Free Radic. Biol. Med., 33: 627-632.

Matthews, R.T., Yang, L., Browne, S., Balk, M. and Beal, M.F. (1998). Coenzyme Q10 administration increases brain mitochondrial concentrations and exerts neuroprotective effects. Proc. Natl. Acad. Sci., 95(15): 8892-7.

Lowry O, H., N.J., Rosebrough, A.L., Farr and Randall, R.J. (1951).Protein measurement with the folin phenol reagent. J. Biol Chem., 193: 265.

Nakamura, K., Noguchi, K., Aoyama, T., Nakajlma, T. and Tanimura, N. (1996). Protective effect of ubiquinone (coenzyme Q9) on ascites in broiler chickens. Br. Poult. Sci., 37:189-195.

Oztay, F., Ergin, B., Ustunova, S., Balci, H., Kapucu, A., Caner, M. and Demirci, C. (2007). Effects of Coenzyme Q10 on the heart ultrastructure and nitric oxide synthase during hyperthyroidism. Chinese J. Physiol., 50(5): 217-224.

Sanni, S.A. and Ogundipe, S.O. (2005). Economics of some modules of poultry production in Kaduna State, Nigeria. Nigerian Journal of Animal Production, 32(1):102-7.

Seifter, S., Dayton, S., Novic, B. and Muntwyler, E. (1949). The estimation of glycogen with the anthrone reagent. Brooklyn, New York.

\section{How to cite this article:}

Ramavathi, J., P. Selvaraj, P. Visha, Manju G. Preeda and Thavasiappan, V. 2019. Liver Total Glycogen, Mitochondrial Protein and CoQ10 Analysis in CoQ10 Supplemented Broiler Chicken. Int.J.Curr.Microbiol.App.Sci. 8(04): 567-573.

doi: https://doi.org/10.20546/ijcmas.2019.804.061 